\title{
ANALYTICAL STUDY OF ABUTMENT AND PILE BEHAVIOUR OF IAB WITH SOIL INTERACTION
}

\author{
M.Keshavamurthy ${ }^{1}$, Pramod $\mathbf{M}^{2}$, Sadath Ali Khan Zai ${ }^{3}$ \\ ${ }^{1}$ Associate Professor, Dept. of Civil Engineering, Bangalore University, Bangalore Karnataka, India \\ ${ }^{2}$ Research student, Dept. of Civil Engineering, Bangalore University, Bangalore Karnataka, India \\ ${ }^{3}$ Associate Professor, Dept. of Civil Engineering, Bangalore University, Bangalore Karnataka, India
}

\begin{abstract}
In this paper, a parametric study was conducted to investigate the effects of various geotechnical properties of the foundation soil on the performance of IAB (Integral Abutment Bridge) subjected to temperature variations from $-20^{\circ} \mathrm{C}$ to $+40^{\circ} \mathrm{C}$. These temperature changes were applied throughout the bridge deck in longitudinal direction. The 3-Dimensional models were prepared using SAP 2000 a Finite Element based software for varying spans and supported on abutments which were connected to the piles. These piles were embedded in the soil up to 40metre depth. The two categories of soils considered in current study were, homogeneous and heterogeneous. Under homogenous, sand with varying angle of internal friction from $29^{\circ}$ to $35^{\circ}$ and clay with varying consistency from firm to very stiff were considered. Under heterogeneous, both sand \& clay were considered with alternate strips of sand and clay, with increasing stiffness at every 5metre strips. In the same way, clay \& rock were also considered with alternate strips of clay and rock with increasing stiffness at every 5metre strips. Behavior of Abutment and piles were studied for different configurations .Analytical results were compared for various spans considered. i.e., $10 \mathrm{~m}, 20 \mathrm{~m}$ and $30 \mathrm{~m}$ span of IAB.
\end{abstract}

Keywords: Integral Abutment Bridges, Soil Pile Interaction, IAB Behavior, Abutment Pile Interaction.

\section{INTRODUCTION}

Bridges are an important element of the infrastructure today. The technical competence has reached high levels in most countries and the limits given to a bridge designer are set by economic restrictions rather than technical skill. The everlasting chase for more economic solutions and procedures includes both a wish for cheaper constructions as well as for a decrease in the maintenance costs.

One of the most common discussed problems concerning bridges built without expansion joints is the accommodation of longitudinal elongation and contraction due to temperature variations. A bridge built with integral abutments is often supported by piles made of steel or concrete. The longitudinal elongation and contraction of the superstructure induces a displacement and a moment in these piles, which in time may cause a fatigue failure. Therefore it is of big interest to look at the amplitude of these strains.

Integral abutments are continuous bridges, where the deck is rigidly connected to the abutments and approach slabs. This rigid connection allows integral bridges to act as a single unit in resisting thermal and brake loads. The need for jointless bridges evolved from the desire to eliminate the use of expansion joints and bearings.

\subsection{Advantages of IAB}

Integral abutment bridges are becoming very popular due to its good response under seismic loading, low initial costs, elimination of bearings, and less maintenance. However the main issue related to the analysis of this type of structures is dealing with soil-structure interaction of the abutment walls and the supporting piles. The interaction between the structure and the adjacent soil media is essential in analysis, and gives a better prediction of the structural behavior compared to the analysis of the structure alone.

\subsection{Bridge Description}

Finite element analysis of a single span of varying lengths of $10 \mathrm{~m}, 20 \mathrm{~m}, 30 \mathrm{~m}$ long and $12 \mathrm{~m}$ wide integral abutment bridge was performed to gain insight into the interactions between the superstructure, the abutment, the foundation piles, and the foundation soil. It was assumed that the bridge superstructure consists of five equally spaced $350 \mathrm{~mm} \times 1500 \mathrm{~mm}$ concrete girders supporting a $240 \mathrm{~mm}$ thick concrete deck, integrated with $5 \mathrm{~m}$ high $1.25 \mathrm{~m}$ thick abutments, which are supported by equally spaced $(2 \mathrm{~m} \mathrm{c} / \mathrm{c})$ seven numbers of $800 \mathrm{~mm}$ diameter concrete piles of length $40 \mathrm{~m}$. The spacing and dimension of piles satisfies the criteria mentioned in the Codes IS 29111985 Part-2 clause 6.6.1 and IRC: 78-2000 clause 709.1.7.

A parametric study was carried out to study the behavior of the pile and abutment of IAB with $0 \mathrm{~m}, 5 \mathrm{~m}$ and $10 \mathrm{~m}$ free 
standing length of the pile.Further, the pile and abutment dimensions were kept same throughout the study to get a realistic comparison of the integral bridge when subjected to different soil types and conditions as mentioned above. As the piles considered are circular in shape, the orientation of the piles does not come into picture. Furthermore, the abutmentpile connection detail was believed to have a significant effect on the abutment and pile moments. Accordingly, a fixed connection detail was assumed between the pile and the abutment to form a rigid connection. The internal forces generated in the abutments and the piles may be a function of the abutment height. Accordingly, the abutment height $(5 \mathrm{~m})$ was chosen on higher side to study the maximum effects. The pile length for all spans of bridges was chosen to be the same i.e., $40 \mathrm{~m}$ long. This pile appears to be oversized for smallerspan bridges, but the research work by Arsoyet. a1. (2002) shows that, stiffer piles result in increased stresses at the pile head, for a given deflection. Full composite action between the slab and the girders was assumed in the model. The length of the piles effective in responding to the lateral temperatureinduced loads and displacements was taken as 30 times the pile width. The portion of the pile below this length is believed to have negligible effect on the pile-soil interaction behavior as the lateral movements of the piles at such depths are insignificant.

A pinned support was assigned at the bottom of the pile to study the maximum displacement and the maximum moments generated at pile head. Unlike the girder, the cross-sections for the piles and abutments did not vary with span length.

\section{3D FEM MODEL}

The modeling of the structure is being done by Finite Element software (SAP 2000 14.2.4). The concrete slab supported by five concrete longitudinal girders and cross beams and abutment, are modeled as shell elements. Seven concrete piles with full fixity are connected to each abutment walls, allowing full moment transfer are modeled as frame element having a common node for pile and the abutment wall. The soil behind abutment and around piles modeled as linear springs.

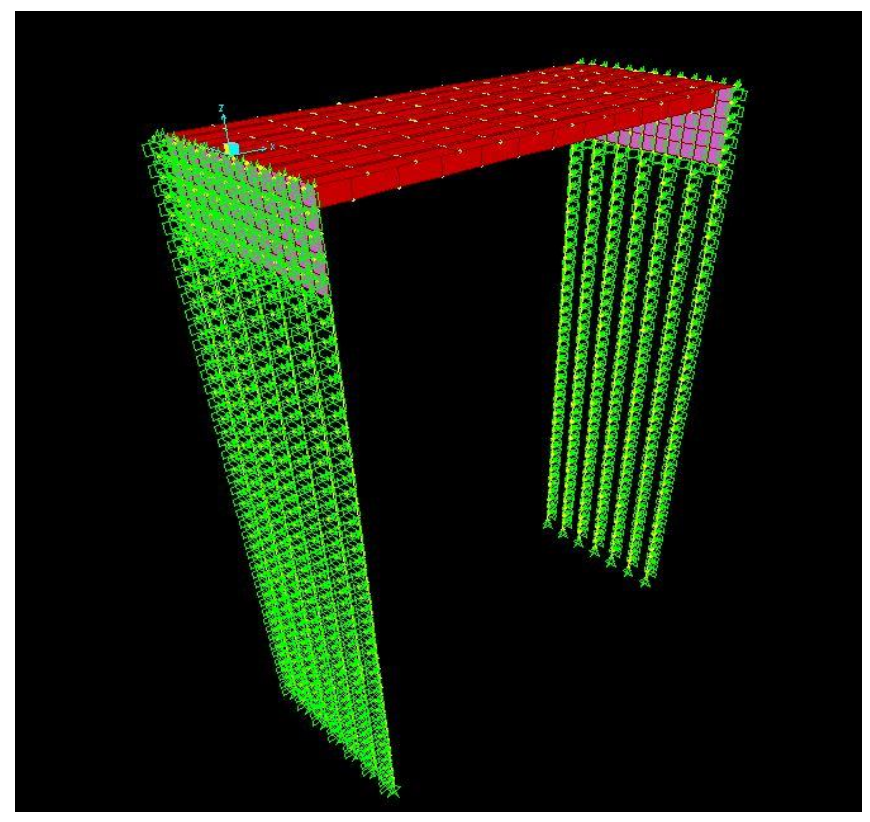

Fig.1: Typical 3D model of IAB

\section{PARAMETERS CONSIDERED IN THE STUDY}

Homogeneous soil

- $\quad$ Sand with varying Friction angle $(\Phi)$ from $29^{\circ}$ with increments of $2^{\circ}$ up to $35^{\circ}$.

- $\quad$ Clay with varying stiffness from stiff to hard.

Heterogonous soil

- $\quad$ Sand and Clay - with increasing stiffness of Sand and Clay of $5 \mathrm{~m}$ strips along the depth of the pile $(0 \mathrm{~m}-40 \mathrm{~m})$.

- $\quad$ Clay and Rock - with increasing stiffness of soil (Clay) from stiff to hard at $5 \mathrm{~m}$ strips along the depth of the pile $(0 \mathrm{~m}-40 \mathrm{~m})$.

The two categories were defined in a manner such that they each provide a different degree of support to the piles. It was assumed that the backfill behind abutment to be well compacted soil with high shear strength, for all the models irrespective of sub soil types and conditions, to provide the most support to the abutment. Hence, the medium sand of friction angle $35^{\circ}$ was considered for soil behind abutment. And the dry unit weight $(\gamma)$ of soil for calculation of Earth pressure behind abutment was assumed to be $18 \mathrm{kN} / \mathrm{m}^{3}$. The intensity of the backfill pressure can be directly calculated using Rankine's theory.

Bowles [11] suggests the values shown in Table 1 for sub grade constant, $\mathrm{k}$, and the unit weight of soil for different relative soil densities. The tabulated values are used for calculation of Lateral Earth pressure at bottom of the abutment. The intermediate values of earth pressure are obtained by interpolation, as it is a linear variation. 
Table1 Properties of sand used

\begin{tabular}{|c|c|c|c|c|}
\hline \multirow[b]{2}{*}{$\begin{array}{l}\text { Soil } \\
\text { property }\end{array}$} & \multicolumn{4}{|c|}{ Relative density } \\
\hline & Loose & Medium & $\begin{array}{l}\text { Medium } \\
\text { dense }\end{array}$ & Dense \\
\hline $\begin{array}{ll}\text { Subgrade } & \\
\text { constant, } \quad \mathrm{k} \\
\left(\mathrm{kN} / \mathrm{m}^{3}\right)\end{array}$ & 2000 & 6000 & 12000 & 18000 \\
\hline $\begin{array}{l}(\Phi) \text { Internal } \\
\text { angle of } \\
\text { friction }\end{array}$ & $30^{\circ}$ & $35^{\circ}$ & $37.5^{\circ}$ & $40^{\circ}$ \\
\hline $\begin{array}{l}\gamma \quad \text { Unit } \\
\text { weight } \\
\left(\mathrm{kN} / \mathrm{m}^{3}\right)\end{array}$ & 16 & 18 & 19 & 20 \\
\hline
\end{tabular}

\section{MODELING OF SOIL}

The soil interacting with the foundation of the structure is modeled by two types of Winkler springs;

- $\quad$ Abutment passive springs

- Lateral springs for piles

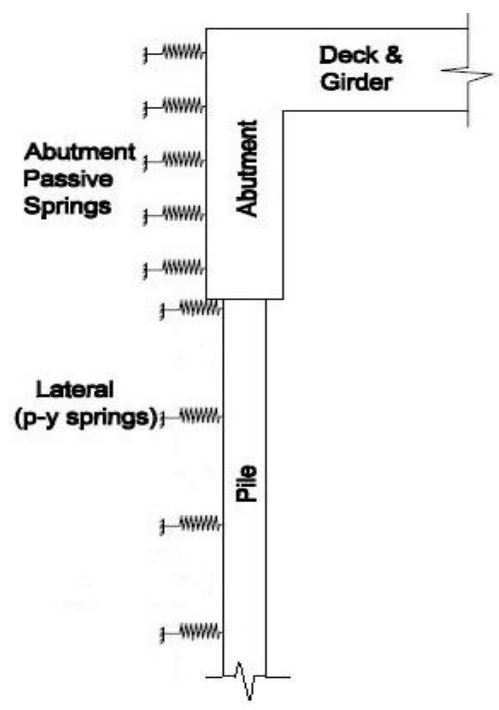

Fig.2 Typical representation of spring stiffness of soil

\subsection{Computation of Abutment Passive Springs}

Abutment is divided into 5 parts of $1 \mathrm{~m}$ depth layers and the springs are provided at each nodal point as shown in Fig.2. Since the passive springs are stiffer than active spring and in most of loading cases the passive condition is predominant and active condition exist only during dead load case and negative temperature load cases, thus only passive springs are adopted instead of active springs.

A Range of values for modulus of sub grade reactions $(\eta)$ assuggested by Swami Saran[12] for different relative soil densities is shown in Table No.2
Table 2.Modulus of sub grade reaction $(\eta)$

\begin{tabular}{|l|l|}
\hline Soil & Passive (kN/m) \\
\hline Loose sand & $400-600$ \\
\hline Medium Dense sand & $800-1200$ \\
\hline Dense sand & $1600-2400$ \\
\hline
\end{tabular}

For the abutment of height $\mathrm{H}$, divided into a convenient number of equal segments of height $\Delta \mathrm{h}$, the reactions and hence the spring constants at various division points would be as under,

$$
\begin{gathered}
\mathrm{k}_{1}=1 / 6^{*} \eta *(\Delta \mathrm{h})^{2} . \\
\mathrm{k}_{2}=\eta *(\Delta \mathrm{h})^{2} . \\
\mathrm{k}_{\mathrm{i}}=(\mathrm{i}-1)^{*} \eta *(\Delta \mathrm{h})^{2} . \\
\mathrm{k}_{\mathrm{n}}=1 / 6 *(3 \mathrm{n}-4) * \eta *(\Delta \mathrm{h})^{2} .
\end{gathered}
$$

Where $\mathrm{k}_{1}$ and $\mathrm{k}_{\mathrm{n}}$ are the spring constants at the top and bottom most pointsk $\mathrm{k}_{\mathrm{i}}$, the spring constant at any division point ' $\mathrm{i}$ ' and $\eta$ is the constant of sub grade reaction.

\subsection{Computation of Lateral Spring Stiffness}

For Homogenous soil, the angle of internal friction $(\varnothing)$ of range $29^{\circ}$ to $35^{\circ}$ were assumed to define the variation in the density (loose to medium dense) of sand surrounding the pile. The values of co-efficient modulus variation (nh) as quoted by Reese et.al.were considerably higher than those of Terzaghi et al., hence the values quoted by Terzaghi et al., were extracted from Fig. 3 and adopted.

The values shown in Table No.3 of un-drained shear strength $(C)_{u}$ of 50-200 from Tomlinson[10] were used to define the variation in the consistency (firm to very stiff) of clay surrounding the pile. At every $1 \mathrm{~m}$, the nodes are created along the depth of the pile, and at each every node the lateral springs are provided to gain the action of the soil as shown in Fig.2.

For heterogeneous soil, both sand \& clay were considered with alternate strips of sand and clay with increasing stiffness at every 5 metre strips. In the same way, clay \& rock were also considered with alternate strips of clay and rock with increasing stiffness at every 5 metre strips.

The springs were provided $5 \mathrm{~m}$ below from the pile head for $5 \mathrm{~m}$ free standing length and $10 \mathrm{~m}$ below for $10 \mathrm{~m}$ free standing length of piles which were considered in the parametric study. 


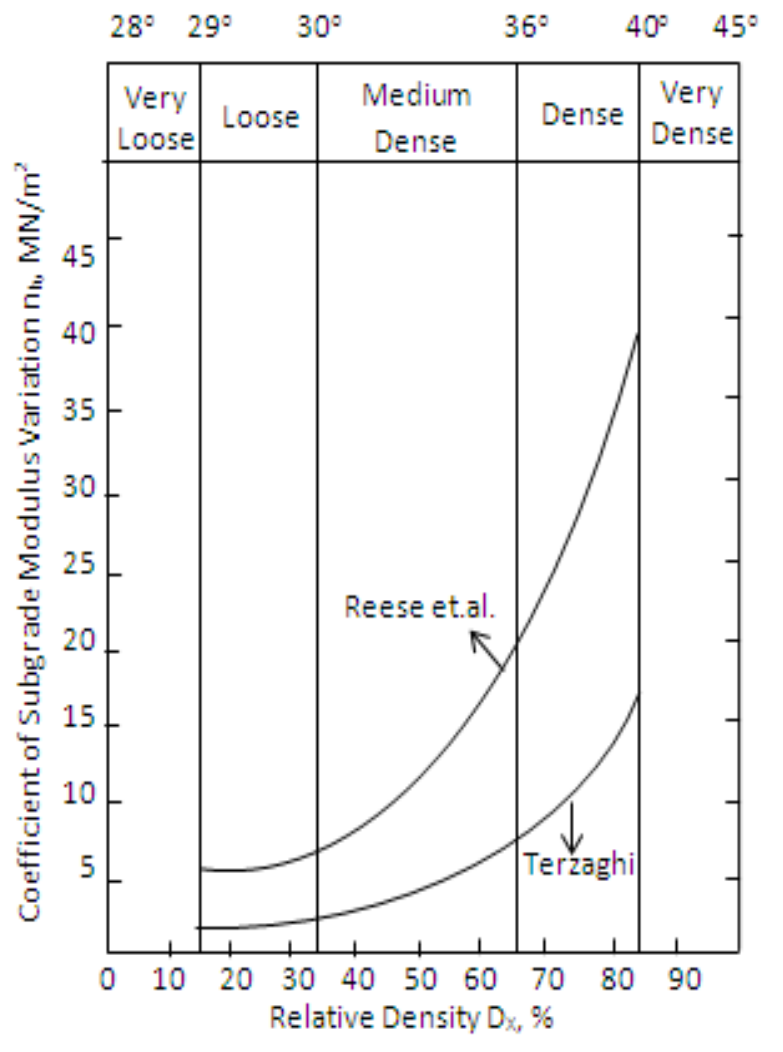

Fig.3: Relation between coefficient of modulus of variation, Relative density and Angle of internal friction

Table 3 Modulus of sub grade reaction $\left(\mathrm{k}_{1}\right)$ to un-drained shearing strength of clay.

\begin{tabular}{|l|l|l|l|}
\hline Consistency & $\begin{array}{l}\text { Firm to } \\
\text { stiff }\end{array}$ & $\begin{array}{l}\text { Stiff to } \\
\text { very stiff }\end{array}$ & Hard \\
\hline $\begin{array}{l}\text { Undrained shear strength } \\
(\mathrm{C})_{\mathrm{u}} \mathrm{kN} / \mathrm{m}^{2}\end{array}$ & $50-100$ & $100-200$ & $>200$ \\
\hline Range of $\mathrm{k}_{1} \mathrm{MN} / \mathrm{m}^{3}$ & $15-30$ & $30-60$ & $>60$ \\
\hline
\end{tabular}

\section{LOADS CONSIDERED}

1) Dead load (DL)

2) Live load(LL), IRC (70R) - as per IRC-6:2000 "Standard Specification and Code of practicesection II".

3) Temperature load(TL): $-20^{\circ} \mathrm{C}$ to $+40^{\circ} \mathrm{C}$.

\section{RESULTS AND DISCUSSIONS}

The results from the analysis for various combinations of load, variations in span, temperature, angle of internal friction of sand, consistency of clay, free standing length of pile were compiled in the form of graphs and tables. The observations are discussed with emphasis towards the behavior of IAB with soil interaction.

\subsection{Abutment Moments}

Table 4 Abutment Moments at centre for Sand of Angle of internal friction $(\Phi)-29^{\circ}$ for $0 \mathrm{~m}$ free standing pile

\begin{tabular}{|l|l|l|l|l|}
\hline $\begin{array}{l}\text { Load } \\
\text { Combinations }\end{array}$ & $\begin{array}{l}\text { Load } \\
\text { cases }\end{array}$ & $\begin{array}{l}\text { 10M } \\
\text { SPAN }\end{array}$ & $\begin{array}{l}\text { 20M } \\
\text { SPAN }\end{array}$ & $\begin{array}{l}\text { 30M } \\
\text { SPAN }\end{array}$ \\
\hline DL+TL $\left(-20^{\circ} \mathrm{C}\right)$ & LC 1 & 276 & 409 & 431 \\
\hline DL+TL $\left(-10^{\circ} \mathrm{C}\right)$ & LC 2 & 171 & 230 & 243 \\
\hline DL & LC 3 & 66 & 51 & 54 \\
\hline DL+TL $\left(+10^{\circ} \mathrm{C}\right)$ & LC 4 & -38 & -128 & -133 \\
\hline DL+TL $\left(+20^{\circ} \mathrm{C}\right)$ & LC 5 & -143 & -307 & -322 \\
\hline DL+TL $\left(+30^{\circ} \mathrm{C}\right)$ & LC 6 & -248 & -486 & -510 \\
\hline DL+TL $\left(+40^{\circ} \mathrm{C}\right)$ & LC 7 & -353 & -665 & -700 \\
\hline DL+LL+TL $\left(-20^{\circ} \mathrm{C}\right)$ & LC 8 & 289 & 433 & 462 \\
\hline DL+LL+TL $\left(-10^{\circ} \mathrm{C}\right)$ & LC 9 & 184 & 254 & 274 \\
\hline DL+LL & LC 10 & 80 & 75 & 86 \\
\hline DL+LL+TL $\left(+10^{\circ} \mathrm{C}\right)$ & LC 11 & -25 & -103 & -102 \\
\hline DL+LL+TL $\left(+20^{\circ} \mathrm{C}\right)$ & LC 12 & -130 & -282 & -291 \\
\hline DL+LL+TL $\left(+30^{\circ} \mathrm{C}\right)$ & LC 13 & -234 & -461 & -479 \\
\hline DL+LL+TL $\left(+40^{\circ} \mathrm{C}\right)$ & LC 14 & -339 & -640 & -668 \\
\hline
\end{tabular}

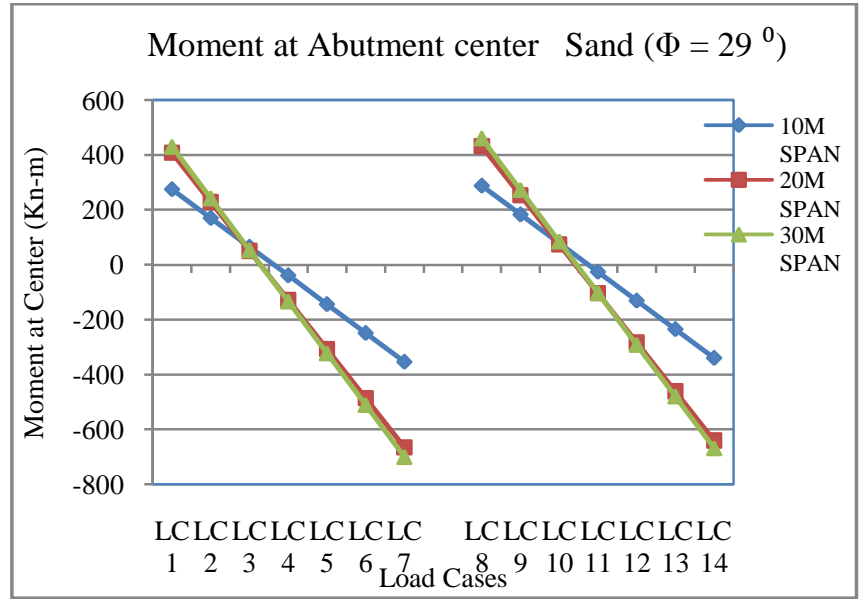

Graph 1 Variation of Moments at Abutment Centre for Sand of Angle of internal friction $(\Phi)$ - $29^{\circ}$ for '0' $\mathrm{m}$ free standing length of pile

1. The expansion and contraction of the bridge superstructure due to the temperature effect can be clearly observed from the Fig No $4 \& 5$ 


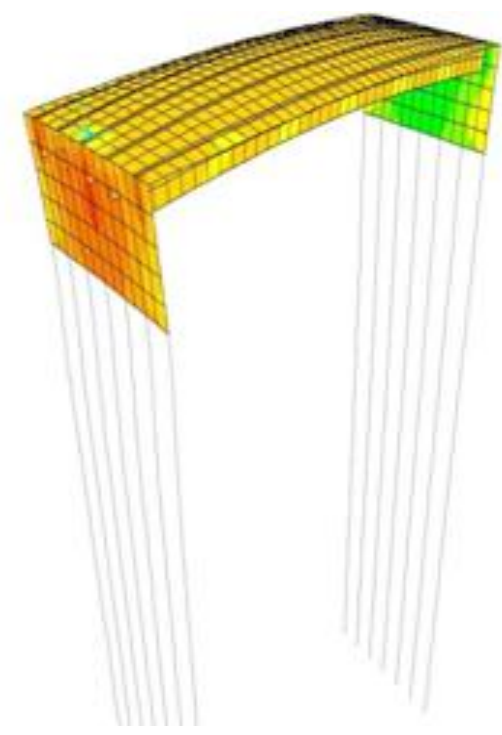

Fig. 4 Typical figure showing Bridge Expansion when subjected to Positive temperature

2. When the positive temperature is considered the bridge deck tends to expand inducing forces on both end supports and the abutment tries to move away, but due to the opposite reaction developed in the abutment and resistance offered by the back fill soil behind the abutment, the abutment is restrained which creates negative moment (Compression).

3. Due to the negative temperature load, the force effects are opposite in nature and thus positive moment is created in the abutment.

4. The increase in span increases the moment at abutment center.

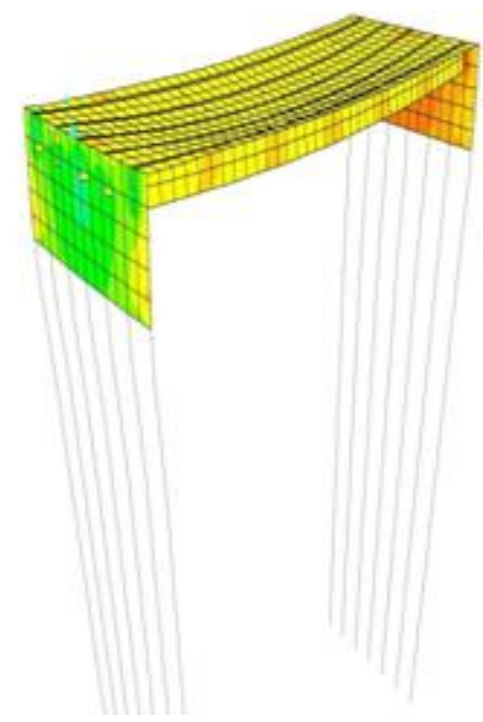

Fig. 5 Bridge Contraction when subjected to negative temperature
5. As the soil friction angle of sand increases from $29^{\circ}$ to $35^{\circ}$, there was a marginal decrease for negative and marginal increase for positive temperature load cases in abutment moment values respectively.

6. The abutment moment was observed to be more than that for soil with $0 \mathrm{~m}$ free standing length. It was seen that the girder deflection was higher as the piles are more flexible inducing rotation of the abutment. As the stiffness of the abutment was much greater than that of the pile or surrounding soil, there is relatively little resistance to this motion, as the rotation of the abutment depends on the dead and live loads. The rotational effect contributes to the additional moment in the abutment.

7. The abutment moment was less when compared to that of Sand, which indicates that sand offers more resistance.

8. The moments were higher at the ends when compared with that at the centre of the abutment. The deflection was observed more in the end girder due to temperature effects which causes more abutment rotation, thereby increasing the moments at the corner.

9. The moments may also be due to the forces transferred from the cantilever portion of the deck slab to the end girders due to thermal effects. Similar trend was observed for all the load cases and soil types.

\subsection{Pile Moment at Pile Head}

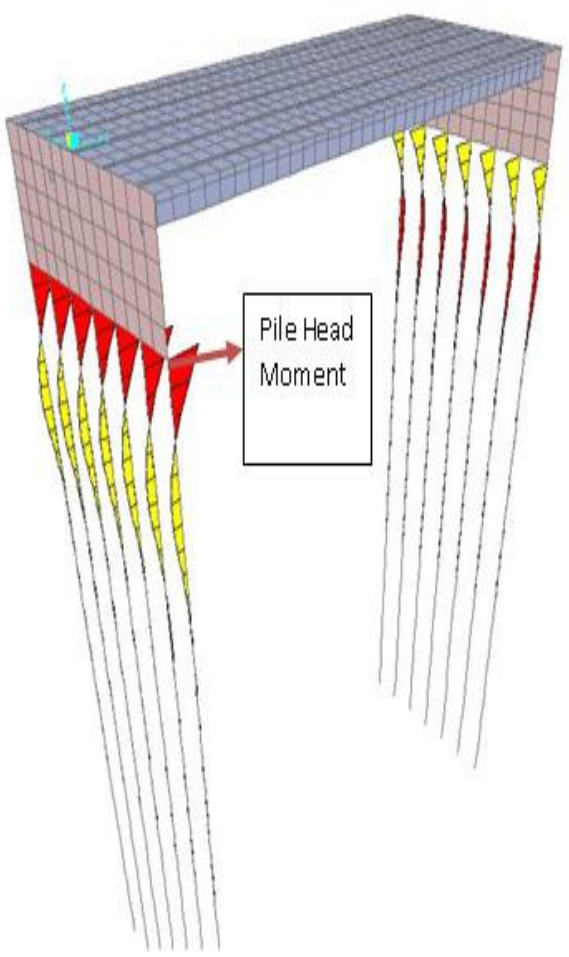

Fig 6 Moment at Pile head 
Table 5 Pile Moments at Pile head for Sand $\left(\Phi=29^{\circ}\right){ }^{\prime} 0$ ' $\mathrm{m}$ free standing length of pile

\begin{tabular}{|l|l|l|l|l|}
\hline $\begin{array}{l}\text { Load } \\
\text { Combinations }\end{array}$ & $\begin{array}{l}\text { Load } \\
\text { cases }\end{array}$ & $\mathbf{1 0 m}$ & $\mathbf{2 0 m}$ & $\mathbf{3 0 m}$ \\
\hline DL+TL $\left(-20^{\circ} \mathrm{C}\right)$ & LC 1 & -788 & -708 & -420 \\
\hline $\mathrm{DL}+\mathrm{TL}\left(-10^{\circ} \mathrm{C}\right)$ & LC 2 & -909 & -853 & -583 \\
\hline $\mathrm{DL}$ & LC 3 & -1014 & -998 & -745 \\
\hline $\mathrm{DL}+\mathrm{TL}\left(+10^{\circ} \mathrm{C}\right)$ & LC 4 & -1127 & -1143 & -908 \\
\hline $\mathrm{DL}+\mathrm{TL}\left(+20^{\circ} \mathrm{C}\right)$ & LC 5 & -1240 & -1288 & -1071 \\
\hline $\mathrm{DL}+\mathrm{TL}\left(+30^{\circ} \mathrm{C}\right)$ & LC 6 & -1353 & -1433 & -1233 \\
\hline $\mathrm{DL}+\mathrm{TL}\left(+40^{\circ} \mathrm{C}\right)$ & LC 7 & -1466 & -1578 & -1396 \\
\hline $\mathrm{DL}+\mathrm{LL}+\mathrm{TL}\left(-20^{\circ} \mathrm{C}\right)$ & LC 8 & -765 & -624 & -266 \\
\hline $\mathrm{DL}+\mathrm{LL}+\mathrm{TL}\left(-10^{\circ} \mathrm{C}\right)$ & LC 9 & -878 & -769 & -428 \\
\hline $\mathrm{DL}+\mathrm{LL}$ & LC 10 & -991 & -914 & -591 \\
\hline $\mathrm{DL}+\mathrm{LL}+\mathrm{TL}\left(+10^{\circ} \mathrm{C}\right)$ & LC 11 & -1104 & -1059 & -754 \\
\hline $\mathrm{DL}+\mathrm{LL}+\mathrm{TL}\left(+20^{\circ} \mathrm{C}\right)$ & LC 12 & -1217 & -1204 & -916 \\
\hline $\mathrm{DL}+\mathrm{LL}+\mathrm{TL}\left(+30^{\circ} \mathrm{C}\right)$ & LC 13 & -1330 & -1349 & -1079 \\
\hline $\mathrm{DL}+\mathrm{LL}+\mathrm{TL}\left(+40^{\circ} \mathrm{C}\right)$ & LC 14 & -1443 & -1494 & -1242 \\
\hline
\end{tabular}

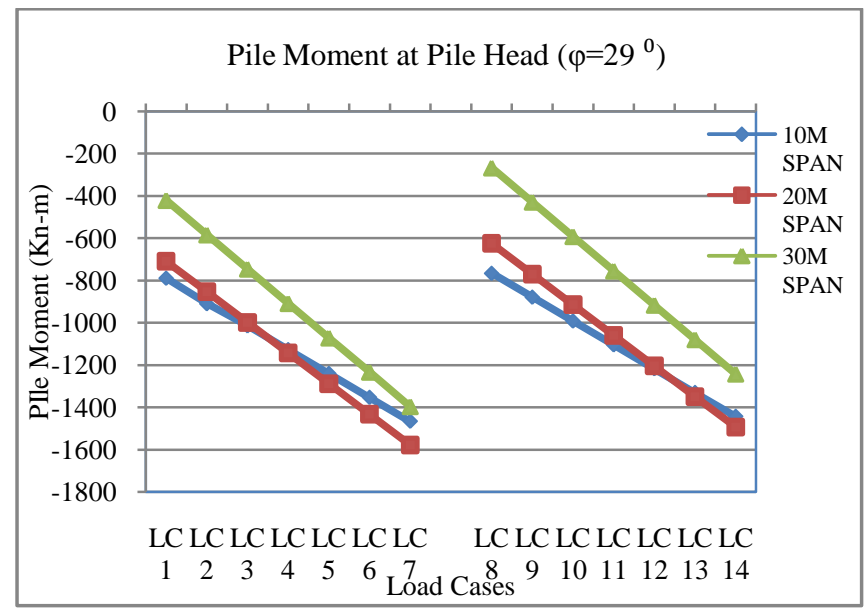

Graph 2 Variation of Moments at Pile head for Sand of Angle of internal friction $(\Phi)-29^{\circ}$ for ' 0 ' $m$ free standing length of pile

1. As the temperature increases, there was increase in pile moment at pile head. When bridge deck is subjected to higher positive temperature the bridge tends to expand thereby exerting force on abutment, but as opposite reaction developed due to backfill, the abutment is restrained, this has the significant influence on the magnitude of the moments developed in the pile at pile head.

2. As the soil friction $(\Phi)$ value increases the moment value increases. This is because the soil friction is directly proportional to the co-efficient of sub grade modulus which in turn is proportional to the lateral spring value.

3. There was considerable decrease in the pile moment at pile head for clay soil than that of sand, this shows that sand is offering more resistance and is stiffer than clay.

4. The Pile moment at pile head decreases as the span increases, this is because as the span increases the moment developed due to the gravity load increases but the same is overcome by the effect of soil pressure which has higher magnitude of negative moment for all the load cases and spans, and hence the decrease in moment.

\subsection{Displacement at Pile Head}

1. The Translation of the pile head is caused mainly by thermal expansion and contraction of the bridge. As temperature is the Governing factor for Lateral Pile displacement, no change in displacement value was observed for DL+LL+TL Load cases.Live Load contributes more for the vertical displacement than the lateral displacement; the magnitude of the displacement only for live load case was very marginal.

2. The increase in span increases the mass of the structure which in turn reduces the displacement. As the free standing length increases the piles become more flexible which increases the displacement.

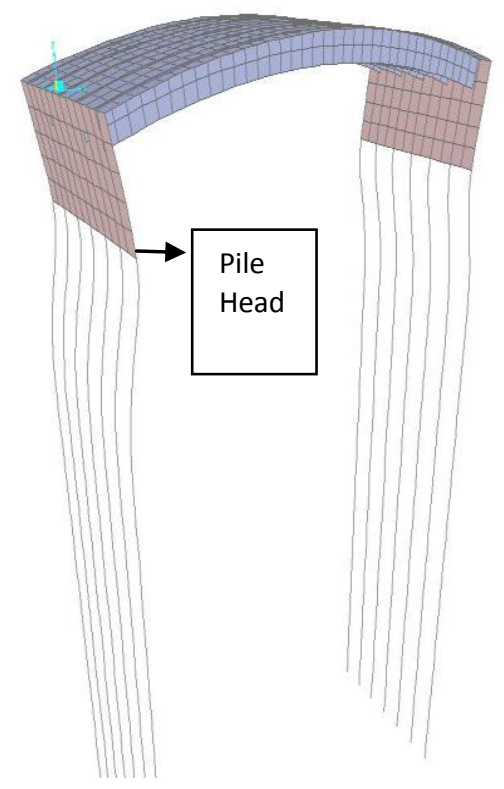

Fig. 7: Displacement at Pile head 
Table 6: Displacements at Pile head for Sand of Angle of internal friction $(\Phi)-29^{\circ}$ for ' 0 ' $\mathrm{m}$ free standing pile.

\begin{tabular}{|c|c|c|c|c|}
\hline $\begin{array}{l}\text { Load } \\
\quad \text { Combinations }\end{array}$ & $\begin{array}{l}\text { Load } \\
\text { Case } \\
\text { s }\end{array}$ & 10 & 20 & 30 \\
\hline $\mathrm{DL}+\mathrm{TL}\left(-20^{\circ} \mathrm{C}\right)$ & LC 1 & 5.00 & 4.88 & 3.48 \\
\hline $\mathrm{DL}+\mathrm{TL}\left(-10^{\circ} \mathrm{C}\right)$ & LC 2 & 5.57 & 5.51 & 4.07 \\
\hline DL & LC 3 & 6.14 & 6.15 & 4.67 \\
\hline $\mathrm{DL}+\mathrm{TL}\left(+10^{\circ} \mathrm{C}\right)$ & $\mathrm{LC} 4$ & 6.72 & 6.78 & 5.26 \\
\hline $\mathrm{DL}+\mathrm{TL}\left(+20^{\circ} \mathrm{C}\right)$ & LC 5 & 7.30 & 7.42 & 5.85 \\
\hline $\mathrm{DL}+\mathrm{TL}\left(+30^{\circ} \mathrm{C}\right)$ & LC 6 & 7.87 & 8.05 & 6.45 \\
\hline $\mathrm{DL}+\mathrm{TL}\left(+40^{\circ} \mathrm{C}\right)$ & LC 7 & 8.45 & 8.68 & 7.04 \\
\hline $\mathrm{DL}+\mathrm{LL}+\mathrm{TL}\left(-20^{\circ} \mathrm{C}\right)$ & LC 8 & 5.00 & 4.89 & 3.48 \\
\hline $\mathrm{DL}+\mathrm{LL}+\mathrm{TL}\left(-10^{\circ} \mathrm{C}\right)$ & LC 9 & 5.57 & 5.53 & 4.07 \\
\hline DL+LL & $\begin{array}{lr}\text { LC } & \\
& 1 \\
& 0\end{array}$ & 6.14 & 6.15 & 4.67 \\
\hline $\begin{array}{c}\mathrm{DL}+\mathrm{LL}+\mathrm{TL}\left(+10^{\circ} \mathrm{C}\right. \\
)\end{array}$ & $\begin{array}{lr}\text { LC } & \\
& 1 \\
& 1\end{array}$ & 6.72 & 6.79 & 5.26 \\
\hline $\begin{array}{c}\mathrm{DL}+\mathrm{LL}+\mathrm{TL}\left(+20^{\circ} \mathrm{C}\right. \\
)\end{array}$ & $\begin{array}{lr}\mathrm{LC} & \\
& 1 \\
& 2\end{array}$ & 7.30 & 7.44 & 5.85 \\
\hline $\begin{array}{c}\mathrm{DL}+\mathrm{LL}+\mathrm{TL}\left(+30^{\circ} \mathrm{C}\right. \\
)\end{array}$ & $\begin{array}{ll}\text { LC } & \\
& 1 \\
& 3\end{array}$ & 7.87 & 8.08 & 6.45 \\
\hline $\begin{array}{c}\mathrm{DL}+\mathrm{LL}+\mathrm{TL}\left(+40^{\circ} \mathrm{C}\right. \\
)\end{array}$ & $\begin{array}{ll}\text { LC } & \\
& 1 \\
& 4\end{array}$ & 8.45 & 8.69 & 7.04 \\
\hline
\end{tabular}

3. As the Angle of Internal Friction $(\Phi)$ of sand is increased the soil becomes more rigid and denser reducing the displacement at pile head. This is because the soil friction is directly proportional to the coefficient of sub grade reaction which in turn is proportional to the lateral spring value.

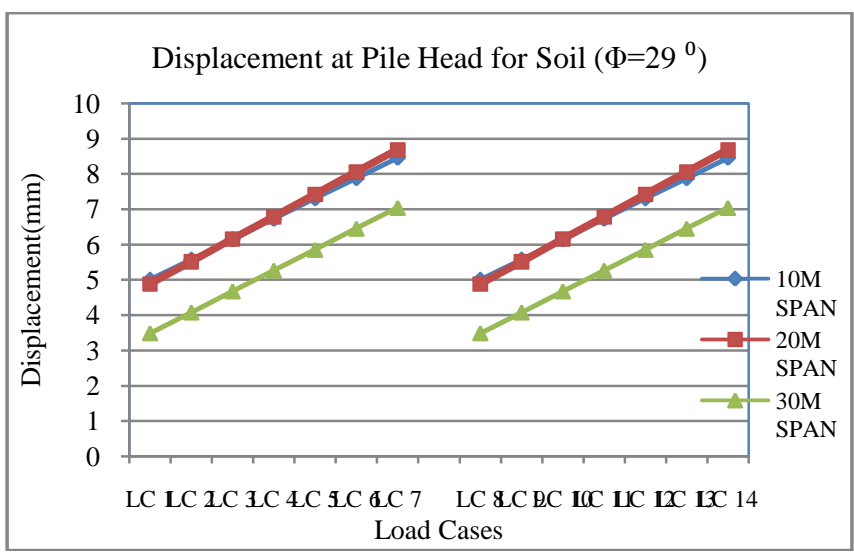

Graph 3 Variation of Displacements at Pile head for Sand of Angle of internal friction $(\Phi)-29^{\circ}$ for ' 0 'm free standing length of pile

4. For less stiffer soil of Sand and Clay, the Pile Displacement was more for Clay, this shows Granular soil (Sand) will provide more lateral restraint at lower range of friction value by reducing the displacement. As the Soil becomes more Stiffer, the displacement value is more for Sand, which clearly shows that Cohesive soil (Clay) provide more lateral restraint at higher consistency.

5. As the abutment moves back and forth under the influence of changing temperature, the piles that support the abutment are subjected to the lateral loads and bending. As the lateral load increases due to increase in temperature the displacement at pile head increases.

6. When the homogenous soil i.e., (Sand $\Phi=29^{\circ}$ and ClayFirm) at lower range of friction angle is considered, the displacement value of the heterogeneous soil (Sand \& Clay) falls in between homogenous soils as mentioned above. It can be interpreted by the observations that heterogeneous soil (Sand \& Clay) is stiffer than clay but less stiff than sand at range of friction angle values mentioned above.

7. The pile displacements observed are much higher when compared with that of homogenous soil $(5 \mathrm{~m}$ free standing length) both at lower and higher range of soil friction value. This shows that homogenous soil are stiffer that heterogeneous soil.

\section{CONCLUSIONS}

The stiffness of integral bridges with longer spans is more effective in reducing the displacement of the pile at the pile head connected to the abutment. Accordingly, greater moments are induced on the pile head at a relatively smaller displacement than that of the small span integral bridges

With the increase in temperature, the displacement at the pile head increases. In order to control the thermal expansion and 
contraction, either the length of the girder must be varied or the magnitude of the thermal movement is to be restricted, to account for the limit state of serviceability. This can be done by varying the prismatic properties of the system i.e., stiffer girders, stiffer abutment and a stiffer pile system/

The systems having longer free standing length are bound to be displacement sensitive; as observed from the results for any type of soil, with free standing length of pile. These flexible systems are sensitive to displacement making way for displacement based design of bridges. This finds significance in the design of railway bridges where displacement becomes critical to avoid derailment

The data analysis showed that as the temperature increases, the abutment moment increases with negative magnitude, resulting in an overall expansion of the bridge during the passive pressure cycles. However, as the temperature decreases, the abutment moment increases with positive magnitude, resulting in an overall contraction of the bridge during the active pressure cycles.

Moment of the pile at its head varies with the sub-surface conditions, piles embedded in a weaker soil, such as firm clay, are more likely to experience yielding than pile embedded in loose granular soils. Therefore, the substructure design in weak clayey soils assumes prominence.

The increase in abutment moments can be attributed to the increase in flexibility of the piles due to free standing length. The rotation induced in abutment due to increase in girder deflection causes the increase in abutment moment. As the stiffness of the abutment is much greater than that of the pile or surrounding soil, there is relatively little resistance to this motion. This rotational effect contributes to the increase in abutment moment.

Thus, the effect of increase in the free standing length needs to be studied with greater depth for predicting the exact behavior of the bridge.

\section{REFERENCES}

[1] Murat Dicleli , P. Eng, Suhail M. Albhaisi(2003) "Maximum length of integral bridges supported on steel H-piles driven in sand" Department of Civil Engineering and Construction, Bradley University, 1501 West Bradley Avenue, Peoria, IL 61625-0114, USA Received 10 March 2003; received in revised form 6 May 2003; accepted 8 May 2003

[2] Thevaneyan K. David, John P. Forth,"Soil structure interaction of Integral Abutment Bridge",School of Civil Engineering, (2005), University of Leeds, UK

[3] R.Shreedar, VinodHosur, Iftikarchappu, "Behaviour of integral abutment bridges with and without soil interaction", International Journal of Scientific \&
Engineering Research, Vol. 3, Issue 11, November2012, 1 ISSN 2229-5518.

[4] YasserKhodair, SophiaHassiotis, "Numerical and experimental analyses of an integral bridge",International Journal of Advanced Structural Engineering, 2013.

[5] IS 2911 (Part 1/Sec 1): 2010 Indian Standard Design And Construction Of Pile Foundations - Code Of Practice, Part 1, Concrete Piles Section 1 Driven Cast In-situ Concrete Piles (Second Revision ).

[6] IS 6403:1981, Indian Standard Code of Practice for determination of breaking capacity of shallow foundations (First Revision).

[7] IRC: 6-2000 Indian Road Congress specification and code of practice for Road Bridges, Section-II, Load and Stresses - (Fourth Revision).

[8] IRC: 21-2000 Indian Road Congress Standard specification and code of practice for Road Bridges, Section-III, Cement Concrete (Plain and Reinforced) (Third Revision)/

[9] IRC: 78-2000 Indian Road Congress Standard specification and code of practice for Road Bridges, Section-VII, Foundation and substructure- (Second Revision)/

[10] M.J.Tomlinson, "Pile Design and Construction Practice", Fourth Edition, E\&FN SPON Publications.

[11] Joseph E. Bowles, P.E., S.E. "Foundation Analysis and Design", Fifth Edition, McGraw-Hill Companies, Inc. New York.

[12] Dr. SwamiSaran,"Soil Dynamics and Machine Foundations", Department of Civil Engineering, University of Roorkee, Galgotia Publications, New Delhi.

\section{BIOGRAPHIES}

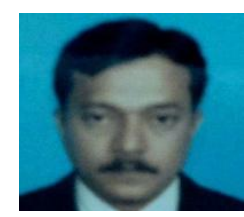

Dr. M. Keshava murthy, Associate Professor, Civil Engineering Department, UVCE, Bangalore, Karnataka.560056

Ph: +917760031217

Email: mkm2503@gmail.com

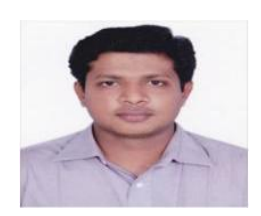

Pramod.M, Research Student, Civil Engineering Department, UVCE, Bangalore, Karnataka.560056

Ph: +919902827330

Email:premd4001@gmail.com

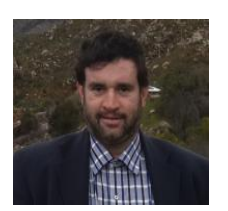

Dr.Sadath Ali Khan Zai, Associate Professor, Civil Engineering Department, UVCE, Bangalore, Karnataka.560056.

Ph: +919844392859

Email:drsakzaiuvce@gmail.com 